\title{
PENGARUH PEMBERIAN FRAKSI ETIL ASETAT BUAH LIBO (Ficus Variegata B.) TERHADAP WAKTU PENYEMBUHAN LUKA SAYAT PADA TIKUS PUTIH (Rattus norvegicus) JANTAN GALUR WISTAR
}

\author{
Maileh Toding, Aditya Fridayanti, Welinda Dyah Ayu, Rolan Rusli* \\ Laboratorium Penelitian dan Pengembangan FARMAKA TROPIS Fakultas Farmasi \\ Universitas Mulawarman, Samarinda, Kalimantan Timur \\ *email: rolan@farmasi.unmul.ac.id
}

\begin{abstract}
ABSTRAK
Buah Libo merupakan salah satu tumbuhan di Indonesia yang telah dilakukan penelitian dan terbukti berpotensi sebagai sumber bahan antioksidan, sitotoksik atau antikanker, pembasmi larva Aedes aegypti dan sebagai antibakteri. Penyembuhan luka merupakan proses yang kompleks sehingga usaha untuk menemukan suatu agen penyembuhan luka yang efektif terus dilakukan. Penelitian ini bertujuan untuk mengetahui potensi fraksi etil asetat buah libo dalam proses penyembuhan luka sayat. Fraksi etil asetat buah libo diperoleh dari proses maserasi dengan -heksan lalu dilanjutkan maserasi dengan pelarut metanol. Ekstrak yang didapatkan dilanjutkan dengan proses fraksinasi menggunakan pelarut etil-asetat. Fraksi diberikan secara topikal dalam tiga tingkatan konsentrasi yaitu 1\%, 5\%, dan 10\%. Fraksi diujikan terhadap luka sayat sepanjang $2 \mathrm{~cm}$ pada punggung tikus. Kontrol positif yang digunakan adalah Povidone Iodine, sedangkan kontrol negatif diberikan air suling sebagai plasebo. Hasil penelitian menunjukkan bahwa fraksi etil asetat buah libo dapat mempercepat menyembuhkan luka sayat pada tikus putih. Kelompok uji dengan konsentrasi $10 \%$ memiliki efek terbaik dalam mempercepat proses penyembuhan luka sayat.
\end{abstract}

Kata Kunci: Penyembuh luka, Luka sayat, Buah Libo, Tikus putih, fraksi etil-asetat.

\section{ABSTRACT}

Libo fruit (Ficus variegat B.) is a plants has potential as a source antioxidant, cytotoxic or anticancer, exterminator larval aedes aegypti, and antibacterial. Wound healing is a complex processes and an effort to find an effective agents of wound healing still continue. The objective of this study was to know potential ethyl-acetate fraction of Libo Fruit on wound healing processes. Ethyl-acetate fraction was made from maceration process with nhexane and continued with methanol. Extracts obtained was continued with fractionation process using ethyl-acetate. Fraction was given topically with three concentration are 1\%, $5 \%$, and 10\%. Fraction was apllied at $2 \mathrm{~cm}$ incised wound at back skin of rats. Positive control group used povidone iodine, and negative control group was given aqua distilled as a placebo. The results showed that ethyl-acetate fraction could accelerate of wound healing on white rats. Concentration 10\% has best effect in accelerating the wound healing.

Keyword : Wound healing, incision wound, Libo fruit, albino rats, ethyl-acetate fraction

\section{PENDAHULUAN}

Istilah luka telah didefinisikan sebagai gangguan struktur anatomi normal. Luka merupakan keadaan yang sering dialami oleh setiap orang, baik dengan tingkat keparahan ringan, sedang atau berat. Hal ini dapat disebabkan oleh fisik, kimia, termal, mikroba, atau imunologi terhadap jaringan. Ketika kulit robek, dipotong, atau tertusuk itu disebut sebagai 
luka terbuka dan ketika trauma benda tumpul menyebabkan memar, itu disebut luka tertutup, sedangkan luka bakar disebabkan oleh api, panas, radiasi, bahan kimia, listrik, atau sinar matahari. Oleh karena itu sangat penting untuk mengembalikan integritasnya sesegera mungkin.

Penelitian mengenai zat yang dapat mempercepat penyembuhan luka merupakan salah satu hal yang sedang berkembang dan banyak dilakukan oleh para peneliti dan praktisi tradisional di seluruh dunia khususnya India dan Cina. Menurut World Health Organization (WHO), 80\% populasi di Negara Asian dan Afrika menggunakan cara pengobatan tradisional yaitu obat herbal karena lebih murah, lebih mudah didapat, dan efek sampingnya yang rendah.

Salah satu tumbuhan yang memiliki khasiat sebagai obat adalah tumbuhan Libo (Ficus variegata Blume). Pohon libo mempunyai buah yang berbentuk bulat seperti kelereng, buahnya bergerombol menempel pada batang maupun cabangnya. Masyarakat menggunakan buah libo sebagai obat diare dan eksim. Buah libo sendiri diketahui memiliki kandungan metabolit sekunder alkaloid, saponin dan fenol dimana golongan metabolit sekunder tersebut mempunyai efek sebagai antibakteri (Utami, 2008). Informasi mengenai tumbuhan ini masih belum banyak terutama penelitian mengenai tumbuhan ini. Namun, telah dilakukan beberapa penelitian terhadap buah dan daun libo kaitannya dengan kefarmasian. Buah libo terbukti berpotensi sebagai sumber bahan antioksidan, sitotoksik atau antikanker, pembasmi larva Aedes aegypti dan sebagai antibakteri (Rijai, 2013).

\title{
METODOLOGI PENELITIAN
}

\section{Bahan}

Bahan yang digunakan dalam penelitian ini yaitu buah libo, n-heksan, metanol, etilasetat, povidone iodine, lidokain dan air suling.

\begin{abstract}
Alat
Peralatan yang digunakan yaitu kandang, kapas, pisau cukur, gunting, labu ukur, pipet, penggaris, skapel, rotary evaporator, timbangan digital, timbangan hewan, sarung tangan, masker, oven, kamera.

\section{Metode Fraksinasi}

Metode pada penelitian ini yaitu pada pengujian luka dimana buah libo diambil secara acak lalu dicuci bersih lalu ditiriskan dan ditimbang berat basahnya. Setelah itu buah libo dikeringkan dengan cara dioven lalu ditimbang berat keringnya sehingga menjadi simplisia. Pembuatan fraksi etil asetat diawali dengan cara menggunakan metode maserasi untuk menarik senyawa yang terdapat dalam buah libo tersebut dengan pelarut $n$-heksan lalu dilanjutkan dengan pelarut metanol. Maserat yang diperoleh dievaporasi dengan menggunakan rotary evaporator. Hasil evaporasi dianginkan-anginkan untuk menguapkan sisa pelarut yang masih terdapat pada ekstrak sehingga diperoleh ekstrak kental. Ekstrak yang diperoleh dilanjutkan dengan proses fraksinasi dengan menggunakan pelarut etilasetat. Fraksi yang diperoleh dibuat variasi konsentrasi yang digunakan sebagai uji, sedangkan povidone iodine sebagai kontrol positif dan air suling sebagai kontrol negatif.
\end{abstract}




\section{Pengujian Luka}

Digunakan 15 hewan uji tikus putih jantan yang dibuat 5 kelompok, setiap kelompok terdiri dari 3 ekor tikus. Dibuat luka sayat pada punggung tikus dimana rambut bagian punggung atas dicukur sehari sebelum dilukai. Pada saat akan dilukai, tikus terlebih dahulu dianastesi dengan lidokain $\mathrm{HCl}$ kemudian di daerah punggung bagian atas dan sekitarnya dibersihkan terlebih dahulu dengan alkohol 70\%. Lalu dibuat luka menggunakan pisau bedah atau skapel dengan cara disayat sepanjang $2 \mathrm{~cm}$ dan kedalaman hingga subkutis dengan cara kulit diregangkan dengan jari telunjuk dan ibu jari tangan kiri sebagai peregang dan penekan. Setelah itu dioles larutan fraksi etil-asetat pada kelompok uji dengan menggunakan 3 variasi konsentrasi, povidone iodine pada kelompok kontrol positif dan air suling pada kontrol negatif. Dihitung lama waktu penyembuhan luka dengan melakukan pengamatan dan pengukuran panjang luka pada hewan uji setiap 24 jam. Hasil data yang diperoleh dianalisis dan dibandingkan, sehingga diperoleh konsentrasi yang paling baik.

\section{PEMBAHASAN}

Bahan baku simplisia buah libo diperoleh dari tanaman di daerah kampus Universitas Mulawarman, Samarinda, Kalimantan Timur. Pengumpulan sampel buah libo dibuat simplisia. Metode ekstraksi yang digunakan adalah metode maserasi yang merupakan metode ekstraksi cara dingin yang sederhana dan tepat untuk digunakan pada simplisia buah yang diduga mengandung antioksidan karena senyawa antioksidan mudah teroksidasi pada proses pemanasan. Proses maserasi dilakukan dengan 2 tahapan yaitu maserasi dengan pelarut $n$-heksana dan dengan pelarut metanol. Tujuan menggunakan pelarut $n$-heksana adalah untuk memisahkan kandungan lateks/getah karena lateks/getah tersebut dapat mengganggu proses selanjutnya, oleh karena itu perlu dilakukan pemisahan antara bagian kandungan buah yang lain dengan lateks atau getahnya. Kemudian dimaserasi dengan pelarut metanol karena sifat kepolarannya yang tinggi sehingga dapat melarutkan baik senyawa polar maupun senyawa non polar. Selanjutnya proses fraksinasi menggunakan metode cair-cair dengan pelarut n-heksane dan dilanjutkan dengan pelarut etil asetat.

Hasil yang didapatkan dari uji pendahuluan menunjukkan konsentrasi $10 \%$ merupakan konsentrasi terbaik dalam penyembuhan luka sehingga digunakan sebagai acuan dalam membuat variasi konsentrasi pada uji sebenarnya. Pada uji fraksi dibuat tiga variasi konsentrasi yaitu $1 \%, 5 \%$, dan $10 \%$, penaikan konsentrasi dilakukan untuk melihat efek penyembuhan luka lebih baik atau sebaliknya. Pemberian dilakukan terhadap 5 kelompok dimana masing-masing kelompok terdiri dari 3 ekor tikus. Kelompok kontrol positif diberikan povidone iodine, kelompok negatif diberikan air suling, kelompok uji 1 diberikan fraksi buah libo 1\%, kelompok uji 2 diberikan fraksi buah libo 5\%, dan kelompok uji 3 diberikan fraksi buah libo $10 \%$. Parameter yang dilakukan saat pengujian adalah lamanya waktu penyembuhan luka ditandai dengan lepasnya keropeng, tidak terjadi inflamasi dan sekitar luka mulai ditumbuhi bulu.

Pada hari ke-0 setelah perlukaan dilakukan, luka masih basah karena eksudasi plasma keluar dari pembuluh darah akibat proses inflamasi, selain itu juga terjadi vasodilatasi dan peningkatan permeabilitas kapiler darah setempat yang menyebabkan kemerahan dan pembengkakkan di sekitar luka. Tahap ini merupakan tahap inflamasi dimana merupakan tahap penting dalam proses penyembuhan luka jaringan kulit. 


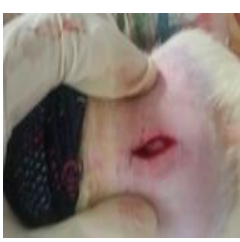

A

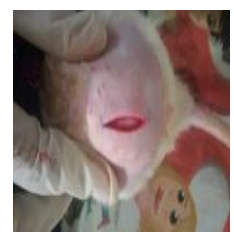

B

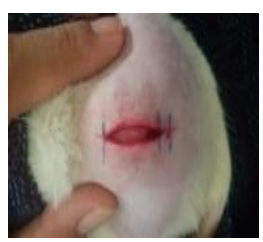

$\mathrm{C}$

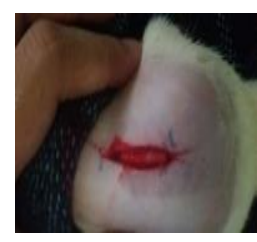

$\mathrm{D}$

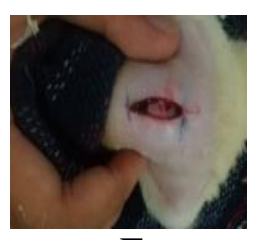

$\mathrm{E}$

Gambar 1. Gambaran makroskopik luka dari kelima kelompok perlakuan. A) Aquades, B) Povidone iodine, C) fraksi buah libo 1\%, D) fraksi buah libo 5\% dan E) fraksi buah libo $10 \%$.

Kelompok kontrol positif merupakan kelompok yang diberikan obat standar dalam penanganan luka yaitu povidone iodine. Povidone iodine merupakan salah satu jenis antiseptik yang juga bekerja pada spektrum yang luas, aktif pada bakteri, virus, dan jamur. Iodofor yang merupakan bentuk umum dari iodine topikal bekerja sebagai pembawa iodine bebas yang merupakan zat aktif. Iodofor meningkatkan kelarutan iodine dan memungkinkan pelepasan lambat dari iodine. Iodofor, sebuah kompleks polimer 1-vinyl-2 pyrolidinone dan suatu zat pelepas halogen melepaskan iodine yang dapat merusak nukleotida, protein kunci, dan asam lemak bakteri yang menyebabkan kematian sel bakteri.

Pada hari ke-2 setelah perlukaan baru terlihat perbedaan diantara kelompok perlakuan dimana keropeng sudah mulai jelas terlihat pada kelompok kontrol positif dan fraksi $1 \%$, kelompok fraksi $5 \%$ dan fraksi $10 \%$, sedangkan untuk kontrol negatif luka hanya mengering, keropeng belum jelas terlihat.

Rata-rata waktu penyembuhan luka (Tabel 1) terjadi di hari ke-6 pada kelompok fraksi $10 \%$ dan mulai ditumbuhi bulu. Dan rata-rata waktu penyembuhan luka untuk kontrol positif yaitu 6,66 hari, kelompok fraksi $1 \%$ rata-rata waktu penyembuhan luka 10 hari, kelompok fraksi 5\% rata-rata waktu penyembuhan luka 9,33 hari dan rata-rata waktu penyembuhan luka untuk kontrol negatif yaitu 12,66 hari.

Tabel 1. Lama Waktu Penyembuhan Luka

\begin{tabular}{ccc}
\hline Batch & Kelompok & Lama waktu penyembuhan luka \\
\hline Batch 1 & Aquades & 14 hari \\
& Povidone iodine & 7 hari \\
& Fraksi buah libo 1\% & 10 hari \\
& Fraksi buah libo 5\% & 10 hari \\
Batch 2 & Fraksi buah libo 10\% & 6 hari \\
& Aquades & 10 hari \\
& Povidone iodine & 7 hari \\
& Fraksi buah libo 1\% & 10 hari \\
& Fraksi buah libo 5\% & 11 hari \\
Batch 3 3 & Fraksi buah libo 10\% & 5 hari \\
& Aquades & 14 hari \\
& Povidone iodine & 6 hari \\
& Fraksi buah libo 1\% & 10 hari \\
& Fraksi buah libo 5\% & 7 hari \\
& Fraksi buah libo 10\% & 7 hari \\
\hline
\end{tabular}


Tabel 2. Rata-Rata Waktu Penyembuhan Luka

\begin{tabular}{cc}
\hline Kelompok & Rata-rata waktu penyembuhan luka \\
\hline Kontrol Negatif & 12,66 hari \\
Kontrol positif & 6,66 hari \\
Konsentrasi 1\% & 10 hari \\
Konsentrasi 5\% & 9,33 hari \\
Konsentrasi 10\% & 6 hari \\
\hline
\end{tabular}

Berdasarkan data pengamatan yang diperoleh bahwa konsentrasi yang paling optimal dalam menutup luka adalah konsentrasi $10 \%$ dengan waktu yang dibutuhkan dalam menutup luka lebih cepat yakni rata-rata 6 hari. Hal ini menunjukkan bahwa pada konsentrasi $10 \%$ memiliki aktivitas penutupan luka lebih cepat bila dibandingkan dengan konsentrasi $1 \%$, konsentrasi 5\%, kontrol positif dan kontrol negatif.

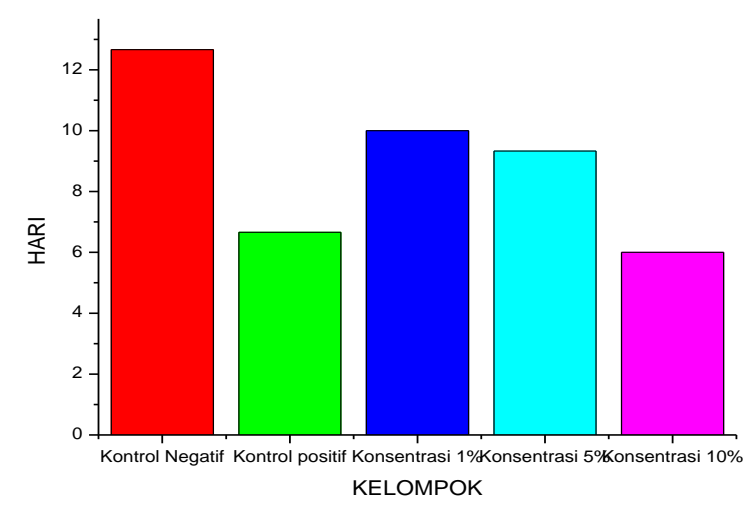

Gambar 2. Rata-rata waktu penyembuhan luka

Pemberian fraksi etil asetat buah libo secara topikal pada luka hewan percobaan meningkatkan aktivitas penyembuhan luka. Peningkatan aktivitas penyembuhan luka ini disebabkan fraksi etil asetat mengandung senyawa alkaloid, flavanoid dan saponin. Kandungan flavonoid dalam buah libo merupakan senyawa pereduksi yang baik, diduga memiliki daya anti inflamasi dan anti bakteri dilihat dari mekanisme kerjanya dengan cara membentuk senyawa kompleks terhadap protein extraseluler yang mengganggu keutuhan membran sel bakteri.

Aktivitas antimikroba dari fraksi etil asetat buah libo menurut beberapa penelitian diantaranya adalah antibakteri terhadap bakteri Gram positif seperti Staphylococcus aureus dan Streptococcus mutans, serta bakteri Gram negatif seperti Pseudomonas aeroginosa, Pseudomonas vulgaris, Klebsiella pneumonia, Salmonella typhimurium, Vibrio cholera dan Escherichia coli, antijamur Candida albicans. Pada penelitian tersebut membuktikan bahwa fraksi etil asetat buah libo mempunyai efek penghambatan terhadap sebagian besar patogen dan merupakan agen antimikroba yang potensial dalam membantu penyembuhan luka. 
Fraksi etil asetat buah libo juga mempunyai efek antioksidan yang poten. Efek antioksidannya ditunjukkan dengan aktivitas penangkapan radikal bebas DPPH, netralisasi hidroksi radikal, dan kemampuan pereduksi. Pada proses penyembuhan luka dilepaskan spesies oksigen reaktif (reactive oxygen species (ROSs)) seperti singlet oxygen, superoksida, dan hidroksi radikal lewat aktivasi dari neutrofil (fagositosis). Radikal bebas dan spesies oksigen reaktif lainnya dianggap sebagai penyebab penting dalam penghambatan proses penyembuhan luka, hal ini dikarenakan stress oksidatif dapat menyebabkan kerusakan pada membran sel, DNA, protein, dan juga lipid dari jaringan tubuh. Suatu obat yang dapat menghambat peroksidasi lipid dan netralisasi ROSs dipercaya dapat meningkatkan keberlangsungan fibril kolagen dengan meningkatkan serat kolagen, meningkatkan sirkulasi, menghambat kerusakan sel, dan meransang sintesis DNA yang berguna dalam proses penyembuhan luka. Sifat antioksidan dari flavonoid berasal dari kemampuan untuk mentransfer sebuah elektron ke senyawa radikal bebas dan juga membentuk kompleks dengan logam. Mekanisme itu membuat flavonoid memiliki beberapa efek, diantaranya menghambat peroksidasi lipid, menekan kerusakan jaringan oleh radikal bebas dan menghambat aktivitas beberapa enzim.

Kelompok kontrol positif merupakan kelompok yang diberikan povidone iodine, dapat dikatakan bahwa povidone iodine sebagai produk paten yang biasa digunakan dalam penanganan luka memang berefek signifikan dalam mempercepat penyembuhan luka dibanding kelompok tanpa pemberian obat apapun (kontrol negatif). Fraksi etil asetat buah libo juga memiliki aktivitas mempercepat penyembuhan luka, mulai dari konsentrasi $1 \%$ dan konsentrasi 5\% sudah memiliki aktivitas mempercepat penyembuhan luka yang signifikan dibandingkan dengan kontrol negatif, kemudian konsentrasi $10 \%$ tidak berbeda signifikan dengan kontrol positif. Hal ini disebabkan karena aktivitas kandungan flavanoid yang terdapat dalam fraksi etil asetat buah libo yang yang dapat mempercepat penyembuhan luka yaitu aktivitas, antiinflamasi, antimikroba, dan antioksidatif.

\section{KESIMPULAN}

Fraksi Etil-asetat buah libo (Ficus variegata B.) dapat mempercepat penyembuhan luka sayat pada tikus putih (Rattus norvegicus) jantan galur wistar dengan konsentrasi terbaik sebesar $10 \%$ dibandingkan konsentrasi 1\%, konsentrasi 5\%, kontrol positif dan kontrol negatif. Disarankan untuk penelitian lebih lanjut terkait efektivitas fraksi etil asetat buah libo terhadap perlakuan yang lain seperti luka bakar. Dan dapat dijadikan sumber bagi peneliti yang hendak mengembangkan penelitian menjadi suatu bahan dasar dalam formulasi sediaan farmasi yang berkhasiat.

\section{DAFTAR PUSTAKA}

Achmad, S. A., 1986, Kimia Organik Bahan Alam. Karunika. Jakarta.

Borkow, G., 2004, Copper's Role in Wound Healing. Cupron. Property of Cupron Inc.

Brander, G. C., Pugh, D. M., Bywayer, R. J., and Jenkins, W. L., 1991, Veterinary Applied Pharmacology and Therapeutic, $5^{\text {th }}$ edition. Baillere Tindal. ELBS: Inggris.

Dahlan, M.,. 2010, Statistik Untuk Kedokteran dan Kesehatan. Edisi ke-5. Penerbit Salemba Medika: Jakarta.

David, S. J., 2010, Buku Statistik Farmasi. Penerbit EGC Kedokteran: Jakarta.

DepKes RI., 2000, Uji Klinik Obat Tradisional. Dirjen POM Depkes RI: Jakarta. 
DepKes RI., 1995, Farmakope Indonesia, Edisi IV. Departemen Kesehatan Republik Indonesia: Jakarta.

DepKes RI., 1986, Sediaan Galenik. Departemen Kesehatan RI:Jakarta.

Diegelmann, R. F., 2004, Wound Healing: An Overview Of acute, Fibrotic And Delayed Healing. Frontiers in Bioscience 9. Hal. 283-289

Dunn, M. D. Ph. D., David, L., 2002, Ethicon Wound Closure Manual. Ethicon inc. American.

Febrina, L., Rusli, R., Muflihah, F., 2015, Optimalisasi Ekstraksi dan Uji Metabolit Sekunder Tumbuhan Libo (Ficus variegata Blume). Journal of Tropical Pharmacy and Chemistry, 3. (2).74-81. DOI: https://doi.org/10.25026/jtpc.v3i2.153

Harbone, J.B., 1987, Metode Fitokimia Penuntun Cara Modern Menganalisis Tumbuhan. Penerbit ITB: Bandung.

Kozier, B., Erb., \& Oliver, R., 2004, Fundamental of nursing; consept, process and practice, Edisi 4. California: Addison-Wesley Publishing CO

Perdanakusuma, D. S., 2007, Anatomi Fisiologi Kulit dan Penyembuh Luka. Airlangga University School of Medicine: Surabaya.

Ratnaningtyas, N., 2010, Pengaruh Pemberian Ekstrak Kulit Buah Delima Merah (Punica $\underline{\text { Ganatum) }}$ Terhadap Jumlah Eritrosit dan Kadar Hemoglobin Pada Tikus Putih (Rattus $\underline{\text { norvegicus) }}$ yang di Papar Gelombang Elektromagnetik Ponsel. Skripsi Fakultas Kedokteran, Universitas Sebelas Maret. Surakarta.

Rijai, L., 2013, Potensi Tumbuhan Libo (Ficus Variegata, Blume) Sebagai Sumber Bahan Farmasi Potensial. Journal Tropical Pharmacy and Chemistry. 2 (3). 167-179. DOI: https://doi.org/10.25026/jtpc.v2i3.63

Riwidikdo, H. 2008, Statistik Kesehatan. Mitra Cendikia Press. Yogyakarta.

Rusli, R., Hardina, M.P., Muflihah, F., Rahmadani, A., 2015. Profil Kromatografi Senyawa Aktif Antioksidan dan Antibakteri Fraksi N-Heksana Daun Libo (Ficus variegata Blume.). Journal of Tropical Pharmacy and Chemistry, 3. (2). 124-130. DOI: https://doi.org/10.25026/itpc.v3i2.98

Sarker, S. D., Lutfun, N., 2007, Kimia Untuk Mahasiswa Farmasi. Pustaka Pelajar: Yogyakarta.

Sarker, S. D., Lutfun, N., 2009, Kimia Untuk Mahasiswa Farmasi, Bahan Kimia Organik, Alam dan Umum. Pustaka Pelajar: Yogyakarta.

Sastrohamidjojo, H., 1996, Sintesis Bahan Alam. Gadjah Mada Press: Yogyakarta.

Semer, N,. 2003, The HELP Guide to Basics of Wound Care. Global-Help Organization. USA. Hal. 3-9

Simanjuntak, M., 2008, Ekstraksi dan Fraksinasi Komponen Ekstrak Daun Tumbuhan Senduduk (Melastoma malabathricum. L) Serta Pengujian Efek Sediaan Krim Terhadap Penyembuhan Luka Bakar. USU Reposity: Medan. Hal. 24-37

Thakur, R., 2011, Practices in Wound Healing Studies of Plants. Review Article. EvidanceBased Complementrary and Alternative Medicine. Hindawi Publishing Corporation

Voight, R., 1994, Buku Pelajaran Teknologi Farmasi, diterjemahkan oleh Noerono, S., Gadjah Mada University Press: Yogyakarta.

Vogel, A.I., \& Tatchell, A. R., Furnis, B. S., Hannaford, A. J. And P. W. G. Smith. 1996, Vogel's Textbook of Practical Organic Chemistry, $5^{\text {th }}$ Edition. USA: Prentice Hall. 